\title{
Pollen grain of barley (Hordeum vulgare L.) - pattern of development
}

\author{
MARIA CHARZYŃSKA*, NELLA LENART
}

Department of Plant Physiology II, University of Warsaw, Krakowskie Przedmieście 26/28, 00-927 Warsaw, Poland

(Received: December 6, 1988. Accepted: February 17, 1989)

\begin{abstract}
Pollen development in barley follows the general pattern established for other species of Poaceae: 1) microspore division occurs at the vacuolate microspore stage with polarly located nucleus; 2) microspore mitosis is immediately followed by phragmoplast and cell plate formation; 3 ) in consequence or unequal microspore division, the generative cell, at first attached to the pollen wall, is separated from the vegetative cell by a callosic wall; 4) during the postmitotic two-cell stage of development, the vegetative nucleus migrates to the aperture pole and is followed by the generative cell that is detached and free of callose wall. In this position the generative cell divides into two sperm cells. These data do not confirm the interpretation of pollen grain development in barley given by $\mathrm{Cass}$ and $\mathrm{K}$ a ras in Can. J. Bot. 53: 1051-1062, 1975.
\end{abstract}

Key words: pollen development, Hordeum vulgare, Poaceae

\section{INTRODUCTION}

Recent reports generally accept that the crucial cytological events which occur during the development of angiosperm pollen grains are those which have been established in the classical works and have previously been reviewed (Maheshwari 1950, Vazart 1958, Heslop-Harrison 1972). More than ten years ago Cass and Karas (1975) described the development of barley pollen grains as essentially deviating from the development pattern of Poaceae

* Correspondence and reprints 
in all crucial stages: microspore division, development of the generative cell and formation of two sperm cells. This work has so far been cited (e.g. Mogensen and Rusche 1985, Shivanna and Johri 1985) without criticism.

In this report we present our results on barley pollen grain development at the light microscopical level, in particular with regard to the spatial relationships within the pollen grains during microscope division, the two-cell postmitotic stage, as well as during division of the generative cell and sperm cell formation.

\section{MATERIALS AND METHODS}

Plants of spring barley, Hordeum vulgare L. var. "Aramir" used in this study were grown under field or greenhouse conditions. We noted no correlative differences related to the pollen grain development; therefore all the data presented concern the former plants.

The material was taken from the main spikes of plants in their successive stages of development. Anthers were dissected from florets of spikelets in the middle part of the spikes because of: 1) considerable synchrony of pollen grain development in anthers within these florets, 2) formation of fertile tricellular pollen grains during heading/flowering stage, 3) missing of developmental disturbances which frequently occur in the lower and upper spikelets on the spike.

On anther from each floret was squashed in aceto-orcein to ascertain the stage of development, the remaining two were fixed in CrAF fixative (0.5-1-20 chromic acid, glacial acetic acid, formaline - in per cent water solution), dehydrated in an ethanol series, taken through xylene and embedded in paraffin wax (Gurr, m.pt. $56^{\circ} \mathrm{C}$ ). Transverse sections of the anthers were cut at $5 \mu \mathrm{m}$ and stained by the Feulgen technique with alcian blue (Pearse 1968) which probably is not specifically bound by both intine and callose walls.

\section{RESULTS}

Transections of anthers of Hordeum vulgare show the microspores forming a single layer at the anther loculus periphery, in accordance with the arrangement typical for Poaceae. The single microspore pore (aperture) is oriented toward the outside of the loculus and is adjacent to the tapetal surface. This configuration is maintained throughout pollen maturity but during slide preparation the pollen grains frequently dislocate to the center of 
the loculus. The single pore of each pollen grain is a stable reference point from which positions of the microspore nucleus, of the generative cell and of the vegetative nucleus within the pollen grain can be established. At the stage of the vacuolate microspore a single vacuole displaces the nucleus from its primary central position to a peripheric one in a thin layer of cytoplasm, not always opposite to the aperture (Fig. 1). Yet, just before and during microspore mitosis the nucleus lies opposite to the aperture (Figs. 2, 3, 4). The mitotic spindle is oriented almost parallel to the pollen grain wall (Fig. 3) and in this position the phragmoplast between the future generative and vegetative nuclei is formed (Fig. 4). The phragmoplast together with the forming cell plate expand laterally, more to the "inside" of the microspore, curves to its wall and the cell plate cuts off the lenticular generative cell attached to the pollen grain wall (Fig. 5). Thus, cytokinesis in the microspore of Hordeum vulgare follows the pattern described in detail by Heslop-Harrison (1968) for the first pollen division in the massula of orchids.

The vegetative nucleus, at first adjacent to the generative cell (Fig. 5), subsequently migrates along the pollen wall toward the pore (Fig. 6) and remains in the adjacent cytoplasm region (Fig. 7).

During migration of the vegetative nucleus the generative cell is, as formerly, located opposite the pore and its wall stains with alcian blue in the same manner as intine of the pollen wall (Fig. 7). Alcian blue probably is unspecifically bound by both intine and callose walls. At this time period, the wall of the generative cell also shows fluorescence after aniline blue treatment (undocumented) which is known to be typical for callose. The generative cell then rounds (its boundary) no longer stains by both stains mentioned above (Fig. 8)) and migrates toward the pore region (Figs. 9, 10). This stage was observed with low frequency, hence, it appears that migration of the generative cell is relatively rapid. The displacement of the vegetative nucleus and the generative cell occurs according to the same pattern found in all pollen grains, in the plane perpendicular to the long axis of the anther. In two adjoining poilen grains formed from one tetrad, the tracks of migration are a mirror reflexion of each other.

Both the vegetative nucleus and the generative cell, while moving, are not situated in exactly the same plane of the pollen grain as the aperture. Therefore, these three entities are not always sharply visible at the same time on every section of the pollen grain.

The generative cell located near the vegetative nucleus, at some distance from the aperture, undergoes division (Fig. 11). During pollen maturation the pair of sperm cells remains near the vegetative nucleus, in a slightly polar position in each pollen grain (Figs. 12, 13).

A diagramatic summary of the pollen grain development in barley is presented in Fig. 14. 

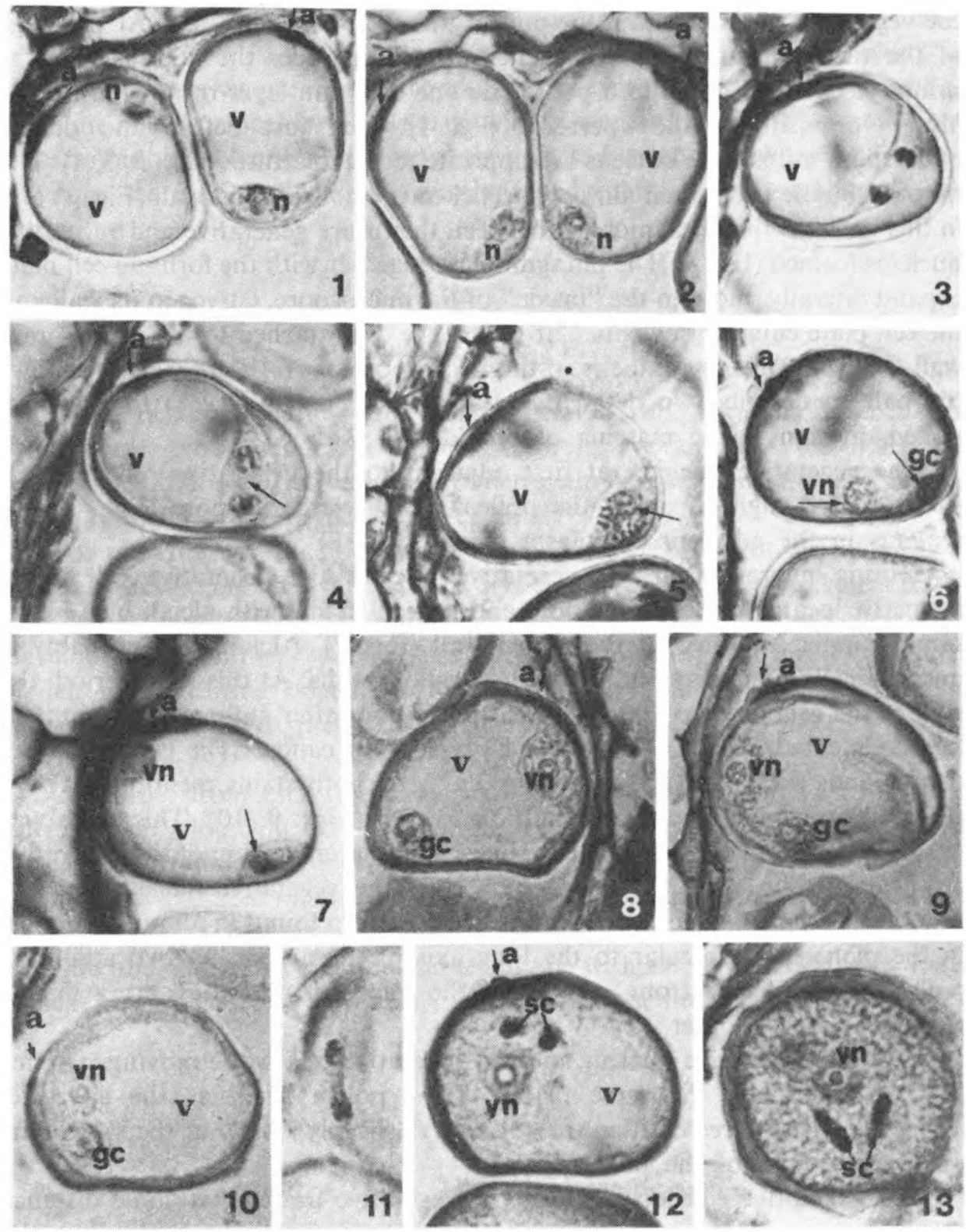

Figs. 1-13. Successive stages of pollen grain development in Hordeum vulgare L., $\times 800$

Fig. 1 - Portion of an anther transection showing two microspores. The microspore nucleus (n) is randomly localized in relation to aperture (a), v - vacuole. Fig. 2 - Highly vacuolated microspores before first pollen mitosis. The nucleus in each microspore is localized opposite to aperture. Figs. 3 and 4 - Telophase of microspore mitosis. In Fig. 4 the phragmoplast with cell plate is forming (arrow). The vacuolate microspores are slightly plasmolized during fixation. 

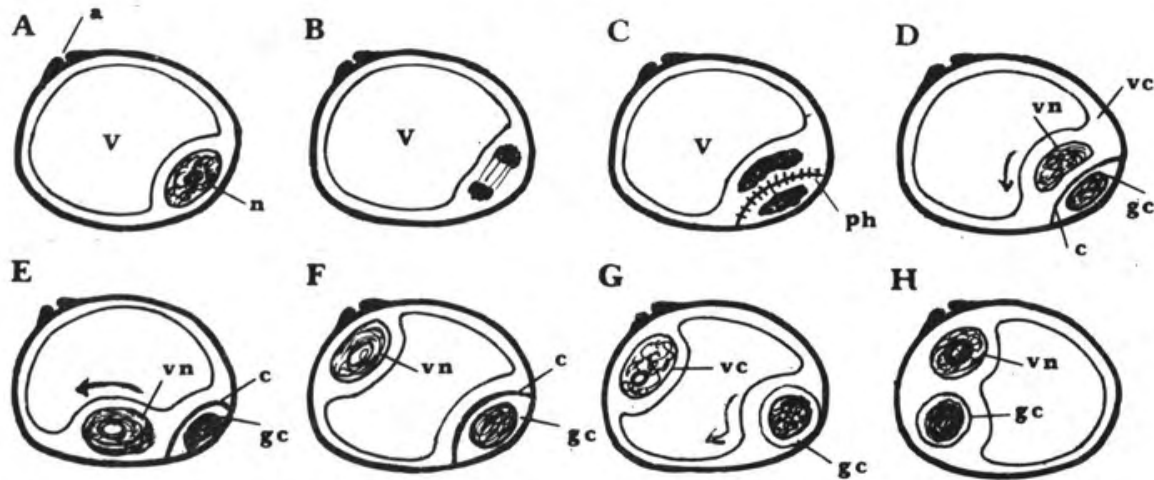

G

H
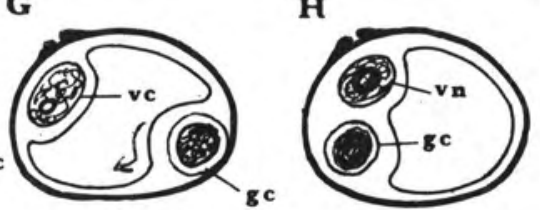

I
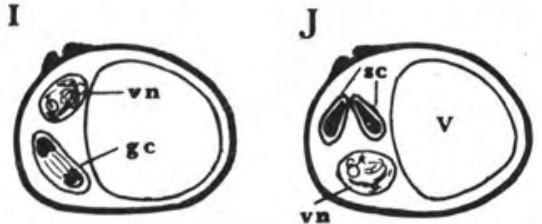

Fig. 14. Diagramatic summary of the pollen grain development in Hordeum vulgare L. (barley). A - microspore just before division; nucleus localized opposite pollen aperture. B-C - microspore mitosis and cytokinesis. D-H - bicellular period of pollen development; vegetative nucleus and generative cell migration to aperture pole. In D-F - callose wall between generative and vegetative cell is present, G-H - after callose wall disolution, I - generative cell division. $\mathrm{J}$ - tricellular pollen grain. Abbreviations: a - aperture, $\mathrm{n}-$ microspore nucleus. $\mathrm{v}-$ vacuole, ph - phragmoplast with forming cell plate, vn - vegetative nucleus, vc - vegetative cell, gc - generative cell, c - callosic wall, sp - sperm cell, arrows - movement direction of the vegetative nucleus and generative cell

Fig. 5 - Late cytokinesis. Generative cell wall (arrow) is visible. Fig. 6 - Postmitotic migration of the vegetative nucleus (vn) to aperture pole. Lenticular generative cell (gc) attached to the pollen wall is not exactly in this plane of section. Fig. 7 - Bicellular pollen grain after translocation of the vegetative nucleus near the aperture. The generative cell (arrow) is still walled and attached to the pollen wall. Figs. 8 and 9 - The generative cell after detachment from the pollen wall (Fig. 8) and during migration to the vegetative nucleus (Fig. 9). Fig. $10-$ Both the vegetative nucleus and the generative cell are situated at aperture pole. The vegetative cell still contains a large central vacuole. Fig. 11 - Portion of the pollen grain with the generative cell at telophase. Figs. 12 and 13 - Maturing tricellular pollen grains. Fig. 12 - longitudinal section in the aperture plane. Sperm cells (sc), vegetative nucleus and aperture are visible. Vacuole is reduced in a polar fashion.

Fig. 13 - The same stage as $\mathrm{Fig}$. 12, a section through aperture pole 


\section{DISCUSSION}

Our observations of pollen grain development in barley do not comply with all of the critical developmental events reported by Cass and Karas (1975, p. 1061). We found that 1) the microspore is highly vacuolated before division; 2) the microspore mitosis is immediately followed by. cytokinesis and a wall formation, hence, the stage of the so called "free naked generative cell" as the result of microspore mitosis does not exist; 3) the generative cell divides atter dissolution of its callosic wall and after detachment from the pollen wall.

The discrepancies in our results and those of Cass and Karas (1975) appear to be explained by the almost complete lack of synchrony among developing pollen grains in the barley plants examined by the above mentioned authors (Cass and Karas 1975, p. 1051). We observed a high synchrony of pollen development; therefore, the sequence of events was determined without doubt.

The so-called "bicellular period" in the development of barley pollen grains consists of several distinct stages (Figs. E, F, G, H in Fig. 14) and occurs in the highly vacuolated pollen. The vacuole regression in the vegetative cell begins after displacement of both the vegetative nucleus and the generative cell in the aperture pole, not before the first pollen mitosis, as noted in grasses Lolium and Phalaris (Vithanage and Knox 1980).

The pattern of development of barley pollen grains presented in this paper is generally consistent with earlier data on the pollen development in other grass species (Batygina 1962, Oryol 1969, 1972, Romanov 1971, Christensen and Horner 1974, Huynh 1975, Gaull et al. 1976, Mostowska and Charzyńska 1977, Młodzianowski and Idzikowska 1978, Vazart 1978, Xi and DeMason 1984, Sunderland and Huang 1987, Charzyńska 1988). Migrations of the vegetative nucleus to the aperture pole of the pollen grain, as well those of the generative cell before its division were documented in Triticum aestivum (Batygina 1962, Romanov 1971) in Zea mays (Oryol 1969, 1972) in Secale cereale (Mostowska and Charzyńska 1977) and in Sorghum bicolor (Christensen and Horner 1974). In Triticum aestivum, Zea mays and Sorghum bicolor, the above-mentioned authors demonstrated by aniline blue fluorescence that the wall that separates the generative cell from the vegetative one and attaches the generative cell to the pollen wall is composed of callose. During migration of the generative cell its boundary no longer stains for callose. Similar results of staining with aniline blue and alcian blue have been obtained for barley pollen. So, it is reasonable to conclude that in Hordeum vulgare movement of the generative cell within the vegetative one begins after dissolution of its callose wall and detachment from the pollen wall as was documented for the first time in other species by Górska-Brylass (1967). 
The biological significance of migration of both the vegetative nucleus and the generative cell to the aperture pole, prior to division of the generative cell, is not known but it appears to be a common feature of pollen development of Poaceae.

\section{REFERENCES}

Batygina T. B., 1962. Microsporogenesis and pollen grain development in wheat (Triticum vulgare var. Diamant). (Transl.) Dokl. Akad. Nauk SSSR, Biol. Sci. Sect. 142: 187-190.

Cass D. D., Karas S., 1975. Development of spérm cells in barley. Can. J. Bot. 53: 1051-1062.

Charzyńska M., 1988. Some aspects of development and division of the generative cell in tricellular pollen grains. Ann. Sci. Univ. Reims 23: 81-84.

Christensen J. E., Horner H. T. Jr., 1974. Pollen pore development and its spatial orientation during microsporogenesis in the grass Sorghum bicolor. Amer. J. Bot. 61: 604-623.

Gaul H., Mix G., Foroughi-Wehr J., Okamoto M. 1976. Pollen grain development of Hordeum vulgare. J. Plant Breed. 76: 77-80.

Górska-Brylass A., 1967. Temporary callose walls in the generative cell of pollen grains. Naturwissenschaften 9: 230-231.

Heslop-Harrison.J., 1968. Synchronous pollen mitosis and the formation of the generative cell in massulate orchids. J. Cell Sci. 3: 457-466.

Heslop-Harrison J., 1972. Sexuality of Angiosperms. In: Plant physiology. vol. 6c. Physiology of development: from seeds to sexuality, F. C. Steward (ed.), Academic Press, New York-London. pp. 133-289.

Huynh K. L., 1975. Un phenomene de polarité peu connu dans'l'anthere des Cyperaces: la position constanté du pore germinatif du pollen. Bull. Soc. Bot. Suisse 85: 18-24.

Maheshwari P., 1950. An introduction to the embryology of angiosperms. McGraw-Hill, New York.

Młodzianowski F., Idzikowska K., 1978. The ultrastructure of another wall and pollen of Hordeuin tulgare at the microspore stage. Acta Soc. Bot. Pol. 47: 219-224.

Mogensen i1. L., Rusche M. L., 1985. Quantitative ultrastructural analysis of barley sperm. I. Occurrence and mechanism of cytoplasm and organelle reduction and the question of sperm dimorphism. Protoplasma 128: 1-13.

Mostowska A., Charzyńska M., 1977. Pollen and sperm nuclei development in rye. Acta Soc. Bot. Pol. 46: 449-457.

Oryol L. I., 1969. Polarity of microspores and movement of nuclei and of generative cell in Zea mays. Rev. Cytol. Biol. Veget. 32: 37-42.

Oryol L. I., 1972. Cytology of male cytoplasmic sterility of corn and other cultivated plants. Acad. Sci. USSR. Sci. Coun. Probl. Cytol. Leningrad Section: pp. 1-83.

Pearse A. G., 1968. Histochemistry theoretical and applied. 1. Churchill LTD, London.

Romanov I. D., 1971. Development du gametophyte male chez le forment (Triticum aestivum L.) d'apres les observations in vivo. Ann. Univ. ARERS 9: 188-194.

Shivanna K. R., Johri B. M., 1985. The angiosperm pollen, structure and function. Wiley Eastern Limited, New Delhi. p. 34.

Sunderland N., Huang B., 1987. Ultrastructural aspects of pollen dimorphism. Int. Rev. Cytol. 107: $175-220$.

Vazart B., 1958. Differenciation des cellules sexuelles et fecondation chez les Phanerogames. Protoplasmatologia 7: 1-156. 
Vazart B., 1978. La division pollinique chez le ble. Bull. Soc. Bot. France Actualit. Bot. 125: $39-$ -43 .

Vithanage H. I. M. V., Knox R. B., 1980. Periodicity of pollen development and quantitative cytochemistry of exine and intine enzymes in the grasses Lolium perenne L. and Phalaris tuberosa L. Ann. Bot. 45: 131-141.

Xi X. Y., DeMason D. A., 1984. Relationship between male and female gametophyte development in rye. Amer. J. Bot. 71: 1067-1079.

\section{Ziarna pylku jęczmienia (Hordeum vulgare L.) - wzorzec rozwoju}

\section{Streszczenie}

Wykazano, że rozwój ziarna pyłku u jęczmienia (Hordeum vulgare L.) przebiega zgodnie ze wzorcem rozwojowym wspólnym dla gatunków z rodziny Poaceae: 1) mikrospora dzieli się w stadium zwakuolizowanym, w którym jej jądro położone jest biegunowo, naprzeciwko apertury; 2) bezpośrednio po mitozie odbywa się cytokineza obejmująca wytworzenie fragmoplastu i przegrody pierwotnej; 3) komórka generatywna, powstała w wyniku różnicującego podziału mikrospory początkowo przylega do ściany ziarna pyłku i oddzielona jest od komórki wegetatywnej ścianą kallozową; 4) podczas postmitotycznego dwukomórkowego stadium rozwoju, jądro wegetatywne jako pierwsze przemieszcza się na biegun ziarna pyłku zawierający aperturę. Komórka generatywna po zaniku ściany kallozowej wnika do komórki wegetatywnej i także przemieszcza się w pobliże apertury obok jądra wegetatywnego. W tym położeniu komórka generatywna dzieli się na dwie komórki plemnikowe.

Przedstawione wyniki nie potwierdzają przedstawionej wcześniej interpretacji rozwoju ziarna pyłku u jęczmienia (Cass and Karas 1975, Can. J. Bot. 53: 1051-1062) przyjmowanej w literaturze jako prawidłowość rozwoju tego gatunku, odbiegającą od wspólnego wzorca rozwojowego trójkomórkowych ziaren pyłku roślin okrytonasiennych. 